\title{
"Formation of strategic management of hemp cultivation in a developing country: A case of Ukraine"
}

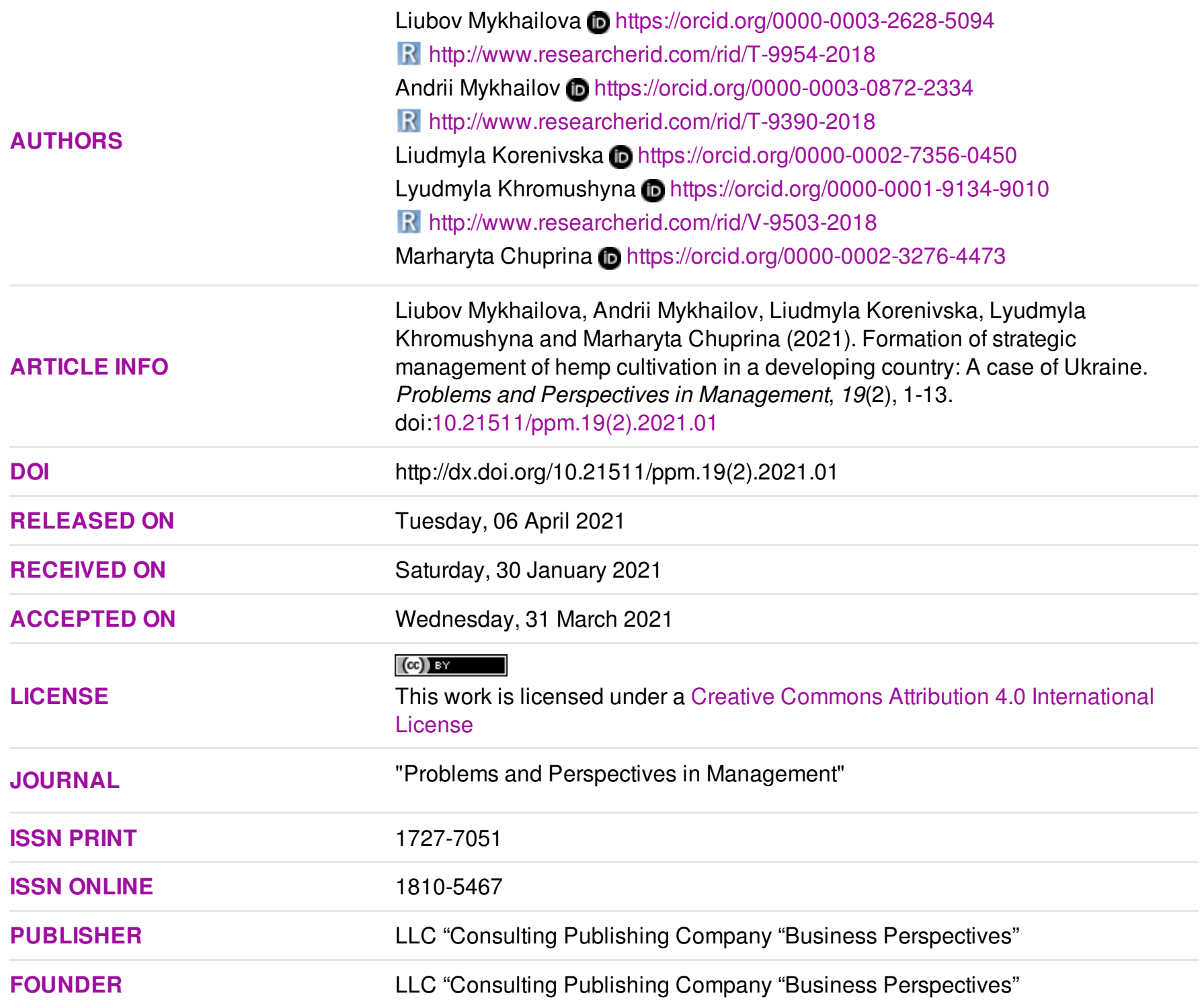

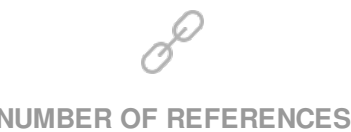

25
NUMBER OF FIGURES

4

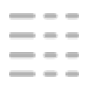

NUMBER OF TABLES

1

(C) The author(s) 2023. This publication is an open access article. 


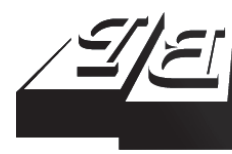

BUSINESS PERSPECTIVES

O

LLC "CPC "Business Perspectives" Hryhorii Skovoroda lane, 10, Sumy, 40022, Ukraine www.businessperspectives.org
Received on: $30^{\text {th }}$ of January, 2021 Accepted on: $31^{\text {st }}$ of March, 2021 Published on: $6^{\text {th }}$ of April, 2021

(C) Liubov Mykhailova, Andrii Mykhailov, Liudmyla Korenivska, Lyudmyla Khromushyna, Margaryta Chuprina, 2021

Liubov Mykhailova, Doctor of Economics, Professor, Department of Management, Sumy National Agrarian University, Ukraine. (Corresponding author)

Andrii Mykhailov, Doctor of Economics, Professor, Head of the Department of Management, Sumy National Agrarian University, Ukraine.

Liudmyla Korenivska, Postgraduate Student, Senior Lecturer, Simon Kovpak Glukhiv Agricultural Institute of Sumy National Agrarian University, Ukraine.

Lyudmyla Khromushyna, Ph.D. in Economics, Associate Professor, Department of Management, Sumy National Agrarian University, Ukraine.

Marharyta Chuprina, Ph.D. in Economics, Associate Professor Department of Management, Nationa Technical University of Ukraine "Igor Sikorsky Kiev Polytechnic Institute", Ukraine.

Liubov Mykhailova (Ukraine), Andrii Mykhailov (Ukraine), Liudmyla Korenivska (Ukraine), Lyudmyla Khromushyna (Ukraine), Marharyta Chuprina (Ukraine)

\title{
FORMATION OF STRATEGIC MANAGEMENT OF HEMP CULTIVATION IN A DEVELOPING COUNTRY: A CASE OF UKRAINE
}

\begin{abstract}
After a long period of decline and persecution, there is a revival and rapid development of the cannabis industry around the world: the use of this unique crop is expanding rapidly, and finally, it was transferred from a narcotic to an agricultural one (except for Ukraine). Nowadays, the Ukrainian hemp industry has practically gone unnoticed by the state, scientists, practitioners and society. At the same time, it has development prospects and can play a significant role for rural areas and the national economy. The paperis aimed at exploring the possibilities of growing hemp (Cannabis sativa L.) and justifying the need for strategic management of the development of the cannabis in dustry in Ukraine. Based on the analysis of hemp production, it is established that during the years of Ukraine's independence, the area of hemp crops has decreased almost 8 times; the number of producers is limited; hemp processing plants do not function; the yield of technical hemp seeds has a slight tendency to increase andapproximates 6-7 $\mathrm{kg} / \mathrm{ha}$. The prospects for cannabis cultivation require building strategic management of the cannabis industry to address key issues and mitigate threats. The key elements of the production development strategy are identified as improving institutional and financial support at the state level. The main guidelines of strategic management of hemp cultivation are: simplification of regulation for producers; intensification of agribusiness entities; increasing production volumes; and improving the competitive environment in the hemp market. It is proved that the strategic development of the hemp industry requires developing hemp processing enterprises; disseminating knowledge among the population about the usefulness and benefits of this multi-purpose culture. To substantiate the effectiveness of strategic decisions, the algorithm was proposed for assessing the effectiveness of growing different types of hemp products by different technologies, which is carried out using economic and mathematical modeling.
\end{abstract}

\section{Keywords}

\section{JEL Classification}

\section{INTRODUCTION}

Hemp has been an indispensable culture since ancient times as it provides food, clothing, textiles, fuel, and medicine. However, every year in Ukraine less and less of this ethnic culture is cultivated. Agricultural producers favor sunflower, corn, soybeans, etc., motivating their choice by established markets, availability of processing plants, stable prices, etc.

It is also important that hemp is biologically compatible with all crops, it is practically free from pests and diseases, and does not need fertilizers. By introducing cannabis into crop rotation, it is possible to increase the production of fodder crops, improve soil fertility and make far fewer fertilizers. Sugar beets, potatoes, silage corn, winter crops, lupines and clover are ideal neighbors for hemp (Zhuplatova et al., 2015). 
Analyzing the studies of foreign authors (Carus, 2018; Adesinaet al., 2020; Tyler et al., 2020)on the composition and structure of products produced based on hemp raw materials, income from its sale at domestic and foreign markets, the ever-growing demand of the planet's population for organic production, it is necessary to note the bureaucratic irrelevance of Ukraine with the development of this industry.

The US and the EU countries do not have their own seed schools, unlike Ukraine. Even the leaders of the modern cannabis market - Canada and France - have not got such schools until now: France, for instance, has steadily imported hemp seeds from Ukraine in recent years. European hemp itself cannot meet the existing demand for hemp fiber. This deficit is partly offset by Ukrainian supplies. Existing conditions in the world hemp production markets guarantee Ukraine a leading position among the main suppliers of hemp raw materials. Also, the growing demand for quality fiber of industrial hemp should lead to the revival and development of Ukraine's own processing industry.

The need for strategic management of the hemp industry development in Ukraine is also exacerbated by the existing public demand for knowledge about using hemp products, agricultural techniques for their cultivation, organizational, economic and environmental aspects of hemp cultivation.

\section{LITERATURE REVIEW}

In the practice of agrarian business of the world's leading countries, the cultivation of hemp is a challenge to the possibility of sustainable agricultural production and production of organic products. The most significant changes in the world began after 1937, when the US government passed the Marijuana Tax Act, which included cannabis (Cannabis sativa L.) in the so-called list of marijuana plants. The U.S. Department of Drug Enforcement, which aims to tighten controls on cannabis cultivation, has virtually destroyed cannabis plantations in North America. Following the practice used in America, cannabis was declared an illegal crop in many European countries immediately after World War II (Inverson, 2000, p. 302). After a 45 -year hiatus in cannabis cultivation in the United States, its rapid revival began.

A certain impetus for the strategic expansion of cannabis production in the world's largest economy was the adoption of the Farm Bill in 2014 (Tyler et al., 2020). After that, cannabis cultivation began to grow rapidly, but to this day there are difficulties and obstacles (competition, market globalization, regulatory policy) that determine the patterns of development of the US cannabis industry. Currently, revenue growth at the global, regional and national levels in each of the sub-segments from 2016 to 2027 is projected from the intensification of the cannabis business. (Tyler et al., 2020).
For Ukraine, which in the 1990s was among the world's leading cannabis producers, the current agrarian transformation creates the preconditions for the revival and development of the cannabis industry. However, the process of "resuscitation" of this industry at the state level is extremely slow, which leads to the loss of a significant share of the foreign market and, consequently, the welfare of the population. Strategic management in the field of cannabis should be aimed at solving socio-economic and environmental problems in rural areas. An increase in the number of cannabis producers will increase the harvest and increase production. This will promote employment in rural areas and create a competitive environment. The hemp development strategy is due to the high environmental benefits of hemp to ensure the sustainable development of rural areas.

D'yakonova et al. (2018) highlighted and assessed strategic management approaches in the system of economic security management and sustainable development of Ukraine. Assessing the development potential of the domestic agrifood market, Dukhnytsky (2019) notes the need for its faster adaptation to the requirements of the world market, taking into account the impact of global trends on the domestic consumer segment. This approach is quite acceptable to characterize the potential for reviving the potential of the cannabis industry in the country, as it is the needs of the global market for 
cannabis products that can motivate domestic producers to expand crops and develop indepth processing of cannabis (Mykhailova \& Korenivska, 2019).

Marchenko (2015) explores the use of cannabis products in the world, which are rapidly expanding due to the versatility of cannabis. Marinchenko and Primakov (2015) explore economic efficiency of hemp cultivation. However, due to limited statistics and sometimes their complete absence, research results are approximate.

Gilyazetdinov et al. (2014) and Migal et al. (2019) analyzed the issues of scientific support of the flax and hemp industries. The Institute of Bast Cultures of NAAS of Ukraine selects new varieties of hemp and provides agro-technological recommendations for growing hemp for agribusiness entities. Given the advantages of having Ukrainian research institutions and growing demand for environmental products, the development of hemp can become a strategic industry that will give impetus to the socio - economic development of the entire Sumy region.

Describing the application of methods and tools of strategic management of agricultural enterprises, Patytska (2019) notes that each producer of hemp products must identify opportunities and dangers of the external and internal environment that will affect its activities in the future. Therefore, for the successful operation of enterprises, it is necessary to develop and improve the existing systems of strategic management at all levels of management of the cannabis industry, which will take into account the peculiarities of growing and processing this crop, as well as related difficulties in choosing and implementing strategy.

Ukraine's integration into the European economic community requires a change in the approach to strategic management of the development of the cannabis industry as a promising component of economic growth in rural areas. Kravets (2014) studied conceptual approaches to strategic management of agricultural enterprises and analyzed the approaches to realizing the purposes of the given concept. Improving the efficiency and ensuring the development of the agricultural enterprise was realized through the attraction of soft loans and subsidies, modernization of production. This approach in the form of "point" financial and administrative support for individual enterprises or industries, government subsidies has shown their ineffectiveness in the long run (Patytska, 2019).

The state of Ukraine's economy requires the introduction into the practice of hemp producers of such strategic management tools that ensure the successful economic activity of European enterprises. One of these effective tools is smart specialization, which will ensure the identification of competitive advantages and assets of the region, the use of its innovative and scientific potential (Yatsyuk, 2018). Smart specialization is an innovative $\mathrm{EU}$ tool for building regional capacity, taking into account the specifics of local conditions, which was developed by economists D. Foray, P. David and B. Hall (Foray et al., 2009). The main participants in this process should be producers, and public administration should provide access to sources of funding and new technologies (Bzhuska \& Pika, 2012).

Development of the regional economy of Sumy region on the basis of smart specialization is the first strategic goal formed by the results of socio-economic analysis and SWOT-analysis, and presented in the Strategy of regional development of Sumy region for 2021-2027 (Strategy of regional development of Sumy region for 2021-2027, 2020). The Structure of the Program of Activities for 20212023 has developed a technical task for creating an agritourism cluster of industrial hemp, which will help create a modern and relevant information space for growing and processing industrial hemp, promote this culture and products of its processing, interest potential investors in the industry.

The Institute of Bast Crops of the National Academy of Agrarian Sciences of Ukraine, which is the originator of elite seeds and resource-saving technologies for growing this crop and in-depth processing, has a decisive place in forming theoretical and methodological foundations of the hemp industry strategic management. The latter is a prerequisite for the choice of basic tools and the formation of key elements and guidelines for strategic management in the field of cannabis in Ukraine. 


\section{AIMS}

The paper is aimed at identifying approaches to assessing the prospects for the revival and formation of strategic management of cannabis cultivation in Ukraine.

\section{METHODS}

Empirical studies of the hemp production process have been conducted using comparative, systematic and graphical analyses. The study of trends in the dynamics and structure of production and processing of all types of hemp products was carried out on the basis of systematic analysis using the statistical and economic methods.

The construction of trends in the area under industrial hemp in Ukraine and the Sumy region, the yield of fiber and seeds of industrial hemp in Ukraine was carried out using correlation analysis, linear and polynomial functions with a selected senior second-order term and a graphical representation in the form of a parabola. Calculation and design methods, as well as a comparison method, were used to assess the current state of cannabis cultivation management in Ukraine and its individual regions.

\section{RESULTS}

It is well known that hemp (Cannabis sativa L.) or cannabis is now a strategic sector of society globally. However, many people associate cannabis products with narcotic substances, which forms a biased attitude towards the consumption and use of goods from this culture. Studies have shown that in recent years, about 30 farms in Ukraine have been sown, some of which continue to grow and others refuse. In 2018, the area of industrial hemp crops in Ukraine did not exceed 1.3 thousand hectares; in 2019, it was planned at the level of 1.5 thousand hectares, whereas in 2016 they were at the level of 3.5 thousand hectares (Figure 1).

Sumy region is the north-eastern region of Ukraine, where in the early 90s of the last century a third of the total area of hemp crops in Ukraine was grown (Figure 1). This was facilitated by the historically accumulated experience of growing bast crops in the region, the operation of processing plants, as well as a strong scientific base in the person of the Glukhiv Institute of Bast Cultures of NAAS of Ukraine.

As shown in Figure 1, expectations for the resumption of the hemp industry in Ukraine are illusory (unreliable). In addition, in the Sumy region, where the Institute of bark crops of the National Academy of Agrarian Sciences of Ukraine is located, they refuse to grow hemp. Built trend line shows not an increase, but a further reduction in acreage technical hemp under existing conditions. Already in 2018-2019, it amounted to 1.5 thousand hectares, and in the Sumy region, this figure decreased to 172 hectares. And this cannot be allowed for the region with the most favorable climatic conditions for the cultivation of crops and the presence of a strong scientific base. Taken together, these factors make it possible to supply competitive goods to the world market.

A historical retrospective of the hemp industry shows that Ukraine sowed over 100,000 hectares of hemp in the Soviet Union, with 35 primary processing plants on its territory. Even if the area of crops in Ukraine is brought to these figures, the Ukrainian market in terms of introduction of a deep and comprehensive free trade area with the EU will only bring millions of dollars into the state budget through the production of seeds and straw alone. If you take the example of an event and allow the cultivation of cannabis for therapeutic use, then legal cannabis earnings will be hundreds of times greater. However, a considerable part of these funds will be paid into the budget in the form of taxes.

To assess the level of informing the population on the production and consumption of hemp products, a sociological survey in the fall of 2019 was conducted. Consumer survey results show that only $76 \%$ of respondents are aware of cannabis products, and $24 \%$ have never heard of it. In addition, $40 \%$ of respondents associate products only with narcotic substances and medicines. This attitude of citizens to the primitive culture in the territory of Ukraine was facilitated by the UN Convention of 1961, which listed cannabis for narcotic substances; this resulted in the decline in its 
12
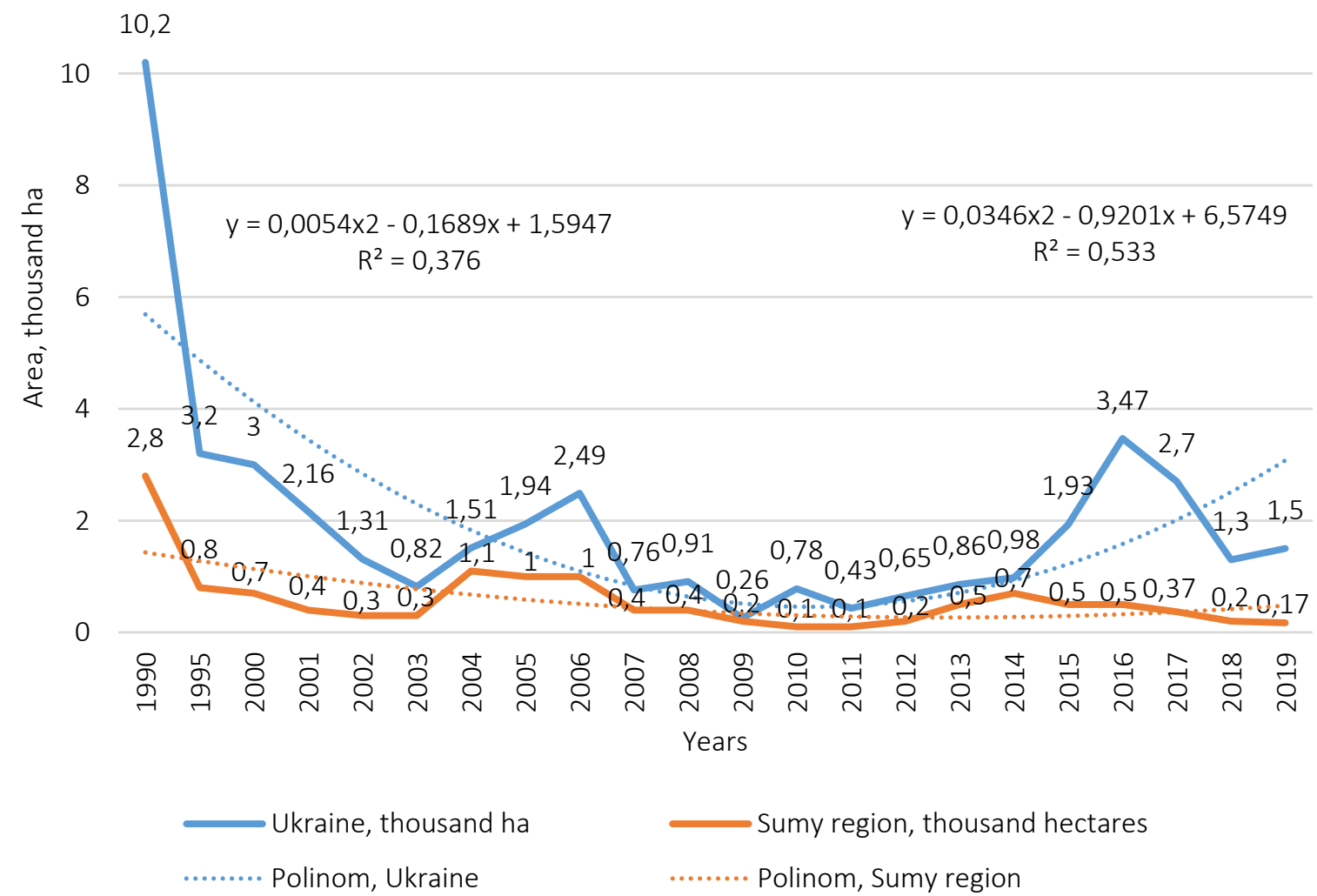

Figure 1. Dynamics of acreage of industrial hemp in Ukraine and Sumy region, thousand hectares

production not only in Ukraine but around the world (Mykhailova \& Korenivska, 2019).

During interviewing manufacturers of hemp production, it was found that the largest percentage of respondents emphasize the following dominant problems impeding the development of their production: lack of Ukraine's interest in the development of hemp industry, rather stringent requirements for obtaining a license, high content of tetrahydrocannabinol industrial (THC) $0,08 \%$. It should be noted that in the EU countries, this figure is $0,2 \%$, and in 2021 it is planned to increase to $0,3 \%$ (Beadle, 2019). Getting a permit to grow hemp is a complicated procedure. In addition, the list of documents that must be submitted for a license includes items that, in the opinion of the manufacturers, only slow down this process.

Hemp production is an industry with a long and expensive production cycle and diverse product. Due to the high price of cannabis products, not every potential buyer can afford it, despite the significant benefits of its usefulness, durability and purpose.

Therefore, manufacturers should not rely on large volumes of the domestic market. Analysis of foreign markets shows that this industry in the world is developing on a "cosmic" scale. With each passing year, the area of crops is increasing, deep processing of hemp production is developing, and foreign markets are saturated with various products of the hemp industry.

The results of empirical research and personal communication between authors and experts - producers give grounds to assert that technical hemp seeds from Ukraine are mainly exported to Europe; in the Middle East, the cooperation with Iran is currently planned. It should also be borne in mind that hemp seeds are a protein bank with unique nutritional value that is in high demand. Several companies are contracting for supplies 
to South and North America, but this market is only opening to Ukrainian manufacturers. In 2019, the Institute of Bast Crops of the National Academy of Sciences of Ukraine cooperated closely with the enterprises and organizations of the People's Republic of China, the USA, Germany, Kazakhstan and Poland.

An important type of hemp production is hemp oil, which is the only natural oil containing in the optimal (3:1) ratio of linoleic and linolenic acid. It is widely used in food (salad oil, margarine, and food additives), technical products (paints, varnishes, printing inks, fuel, solvents, grease, and mastic for grinding, activated carbon), hygienic products (soap, shampoo, gel, cosmetics). Cannabis meal can be used to feed animals for protein enrichment and other needs. Fibers are shipped to Europe in large quantities as raw materials for biocomposite materials. China also buys a lot of long fiber. A small amount of these products goes to the domestic market for the manufacture of textiles.

Given the high usefulness of cannabis production to ensure the quality of life for humanity, more and more countries are developing a legal framework to simplify the business of not only industrial hemp, but also the cultivation and use of hemp for therapeutic (medical cannabis with a THC content of no more than $0.05 \%, \mathrm{CBD}-1.5 \%$ ) and recreational purposes. Therefore, to enter foreign markets, Ukrainian products must have a competitive price and quality that meets European standards.
It should be noted that enterprises and institutions are located in the most attractive regions for the cultivation of technical hemp: in Sumy, Zhytomyr, Poltava and Vinnytsia regions. It is in these regions of Ukraine that the optimal conditions for growing hemp have historically developed, because this crop needs a significant amount of moisture.

In the Sumy region in 2019, only three institutions and enterprises were engaged in growing technical hemp for seeds. Figure 2 presents the structure of sown areas of technical hemp producers located in the Sumy region.

An important factor in shaping the economic potential of hemp production is the yield of hemp varieties. Data on the actual yield of fiber and seeds of technical hemp in Ukraine are presented in Figure 3. It should be noted that the constructed trend lines (Figure 3) indicate an increase in fiber yield to $9 \mathrm{c} / \mathrm{ha}$, and a stable increase in the yield of technical hemp seeds to $7.7 \mathrm{c} / \mathrm{ha}$.

Thus, if in 2010 in Ukraine the seed yield was 6.6 c/ha, then by 2016 it decreased by $0.3 \mathrm{c} / \mathrm{ha}$ and was already $6.3 \mathrm{c} / \mathrm{ha}$. In terms of fiber yield, an increase is observed: from $2.5 \mathrm{c} /$ ha in 2010 to $8.8 \mathrm{c} /$ ha in 2014 (see Figure 3).

For example, the Kravets OP farm in Vinnytsia region received a grant from the European Bank for Reconstruction and Development (EBRD) to conduct research on strategic management and marketing in export markets. In other words, the con-

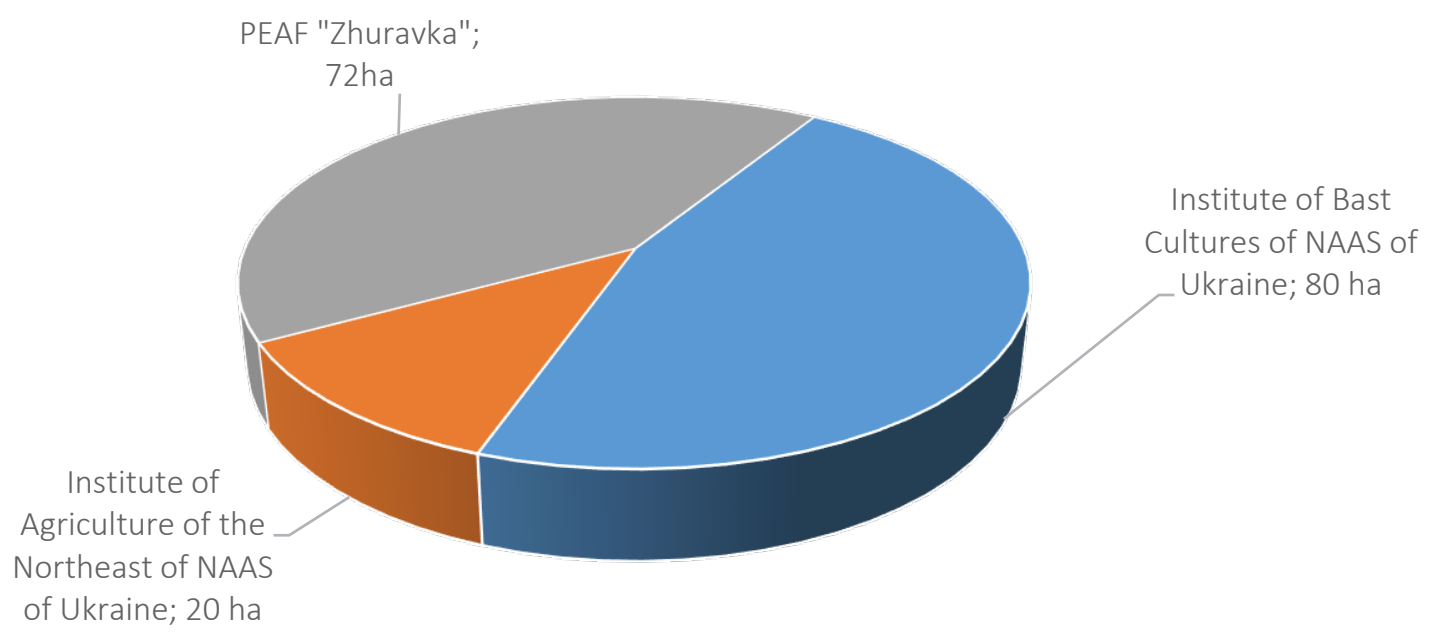

Figure 2. Technical hemp area by enterprises and institutions of Sumy region in 2019, hectares 


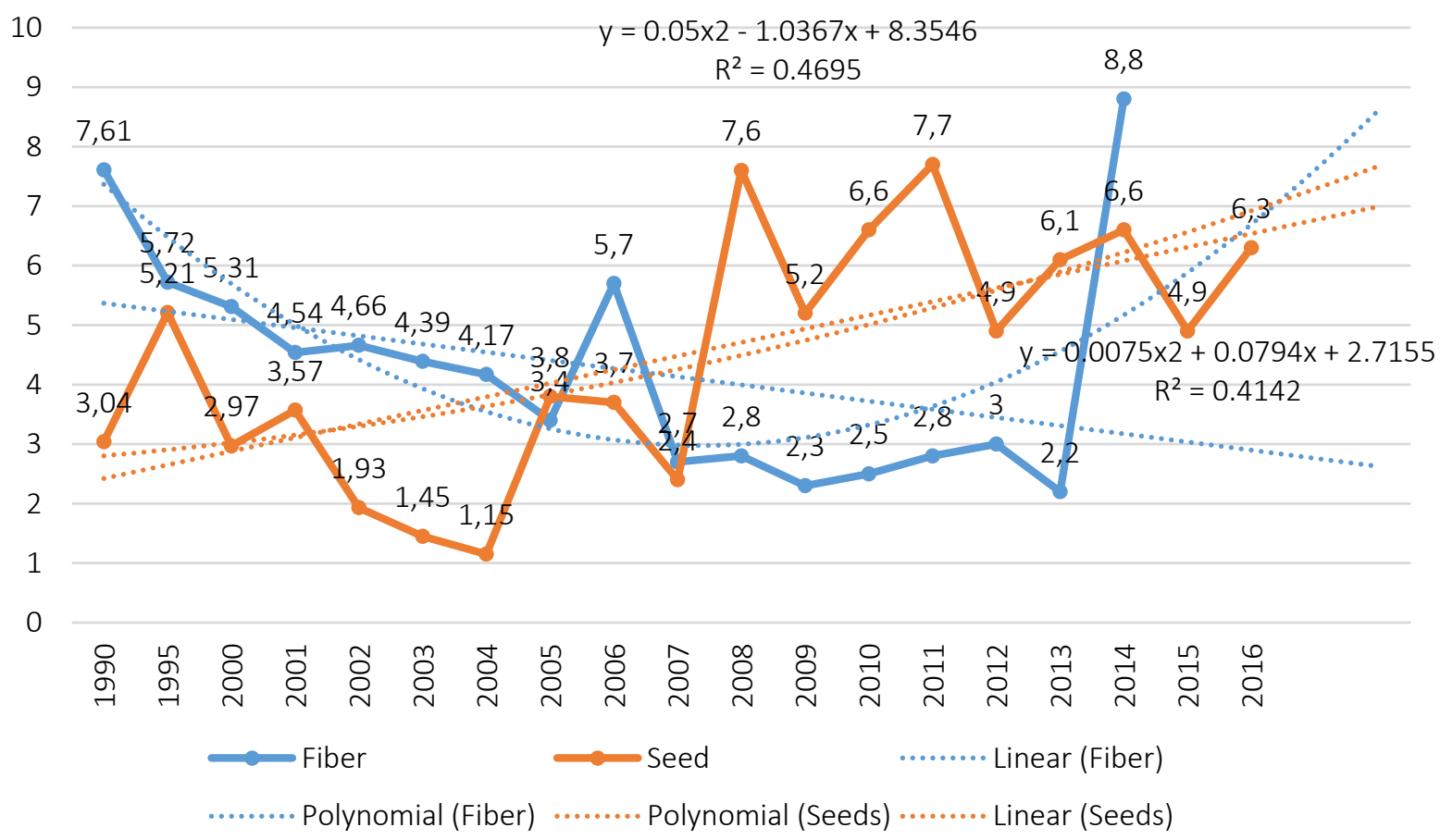

Figure 3. Yield of fiber and seeds of technical hemp in Ukraine, $c /$ ha

sulting company is looking for the most attractive market segments for the farm, as well as countries with high potential for exports. The EBRD pays $75 \%$ of the cost of these studies. The businessperson and his partners signed a five-year contract worth USD 0.5 million for the supply of varietal seeds to Kazakhstan. There, hemp stalks are going to be used as raw materials for papermaking.

The prospects for hemp exports are confirmed by the Ukrainian Hemp Institute, which in 2016, together with the Institute of Bast Cultures of NAAS of Ukraine, signed contracts for the supply of seeds to the United States, Canada and Italy.The reason for this popularity is the unique technical parameters of domestic varieties of hemp. For example, the variety "Glukhivska 51" showed a fiber content of $38.9 \%$ - the highest in the world, and the variety "Glesia" pleases Europeans with a record yield $-2 \mathrm{t} / \mathrm{ha}$ of seeds. For comparison, the Russian variety of hemp "Surskaya" gives only up to 1.1 tons of seeds per hectare (Marinchenko \& Primakov, 2015).

Working with Ukrainian suppliers, Europeans have a double benefit. In the EU, hemp is a special industry that receives government subsidies for sowing and processing hemp: from 200 to 600 euros per hectare. This reduces the cost of technical hemp, which grows from inexpensive and high-quality Ukrainian seeds. One of the promising areas for the cultivation of technical hemp is the cultivation of organic hemp (Ighnatjuk, 2018). For example, FG Pavel Tizesh "Bio", Vinnytsia region, grows organic hemp and, although the owner collects three times smaller yields on each hectare of his field - up to $300 \mathrm{~kg}$ of seeds, the price on world exchanges of such products is 6.45 euros per $\mathrm{kg}$. The products of the farm are completely bought by the companies of Switzerland, Germany and Hungary (Ihnatiuk, 2018).

In 2019, 400 hectares of organic hemp were sown in Rivne region, and 300 hectares in Lviv region. Thus, technical hemp has confidently begun to conquer a market segment such as organic production. In addition, built in 2018 with the help of the Association "Technical Hemp", state-ofthe-art plant for primary processing of technical hemp, which is located on a mobile platform, has significantly increased the profitability of hemp in the Western region of Ukraine. One of the biggest problems in the cultivation of technical hemp is the development of technology and technical 
means during their harvest, because, according to research, seed losses reach $55 \%$ due to the high stem part. Minimal seed losses can be achieved with the use of specialized harvesting equipment.

It should be noted that those wishing to obtain knowledge of the hemp business and to confirm them with the certificate of the state model have the opportunity at the National University of Life and Environmental Sciences of Ukraine (Kyiv) within the framework of the "Hemp University".

Ukraine has two scientific institutions on the territory of Sumy region: Institute of bast crops of NAAS of Ukraine - the owner of varieties of hemp containing non-narcotic substances (Table 1), and Institute of Agriculture of the North-East of NAAS of Ukraine - the developer of high-demand hemp cultivation technologies in Ukraine, Lithuania and Italy.

In addition, it should be noted that the "Arnika" business group has been operating in the Poltava region for more than 15 years, on the basis of which the Breeding Research Institute of Organic Farming and Seeds has been established and successfully operating, which established an interdepartmental hemp laboratory. The result of its work was the removal of new varieties of hemp: Lara, Globa and Sula, which in 2018 were included in the State Register of Plant Varieties of Ukraine.

Consequently, high-quality seed material is not lower than the first reproduction, with technologies of cultivation of hemp, due to the presence of a powerful scientific base in the form of three scientific institutions, actual and potential producers of rural territories are provided with $100 \%$ educational services. The production and processing of hemp production complicates the presence of THC in this culture.

Although its content in hemp varieties is only $0.08 \%$ according to the law, the company must obtain a license for its cultivation. It should be emphasized that it takes up to 4 months to obtain a license. In addition, by November 15, an application must be submitted for a quota indicating the planned areas of hemp crops for the next year.

The situation with processing of hemp production was much worse. As of early 2020, only a few cannabis processing plants are operating in Ukraine. The number of enterprises engaged in growing and processing hemp production is small, about 30 farms.

For the purpose of development of rural territories at the state level according to the program of state support of agriculture (Antonov, 2010), 80\% of the cost (without VAT) of industrial hemp seeds of domestic breeding of categories of basic, certified, but not more than $30,000 \mathrm{UAH}$ is compensated to one farm or agricultural service cooperative.

Nowadays, the necessity for hemp cultivation in the $\mathrm{EU}$ is determined by the need to enhance the diversity of agricultural crops as well as by the fact that hemp is one of the fastest growing crops and it has a huge potential in different spheres of produc-

Table 1. Data from the State Register of Industrial Hemp Varieties as of December, 2019

Source: Based on the Ukrainian Institute for Plant Variety Examination (UIPVE) (2019).

\begin{tabular}{|c|c|c|c|c|c|c|c|c|}
\hline $\begin{array}{c}\text { Application } \\
\text { number }\end{array}$ & $\begin{array}{l}\text { The name of } \\
\text { the variety }\end{array}$ & $\begin{array}{l}\text { Creation } \\
\text { method }\end{array}$ & Applicant(s) & Owner & Patentee & $\begin{array}{c}\text { Year of } \\
\text { registration }\end{array}$ & $\begin{array}{l}\text { Recommended } \\
\text { growing area }\end{array}$ & $\begin{array}{c}\text { Direction } \\
\text { of use }\end{array}$ \\
\hline 82014002 & YUSO 31 & & 393 & 2289 & 2289 & 1987 & $L$ & Fabr \\
\hline 94014002 & Zolotonossky 15 & & 393 & 2289 & & 1998 & L & Fabr \\
\hline 05014001 & Hlyana & & 393 & 2289 & 2289 & 2007 & $L P$ & $\mathrm{Fabr}$ \\
\hline 13080001 & Hlesia & $P$ & 1869 & 2289 & 2289 & 2016 & ELP & Tech \\
\hline 16080002 & Lara & $P$ & 2430 & 2430 & 2430 & 2018 & ELP & Tech \\
\hline 11014001 & Neika & $P$ & 393 & 2289 & & 2012 & & \\
\hline 17080001 & Nicholas & $P$ & 2289 & 2289 & & 2019 & $L P$ & Tech \\
\hline 17080002 & Hlukhivsky 85 & $P$ & 2289 & 2289 & & 2019 & ELP & Tech \\
\hline 16080001 & Globa & $P$ & 2430 & 2430 & 2430 & 2018 & ELP & Tech \\
\hline 09014001 & Victoria & $P$ & 393 & 2289 & & 2011 & & \\
\hline 17080003 & Sula & $P$ & 2430 & 2430 & 2430 & 2019 & ELP & Tech \\
\hline 15080001 & Hlukhivsky 51 & $\mathrm{P}$ & 1869 & 2289 & 2289 & 2017 & ELP & Tech \\
\hline
\end{tabular}


tion (Vilcina et al., 2014). Diversified agricultural production is important in the context of land reform and sustainable development in Ukraine (Mykhailov et al., 2020).

The solution of complex problems of increasing the economic potential for hemp production in Ukraine is possible only on the basis of a systematic approach improving strategic management, implementation of the program-targeted method of development of the hemp industry with active state, regional support and purposeful investment (Mykhailova \& Korenivska, 2020).

It can be concluded that the main reason for the threatening situation of the cannabis industry in Ukraine is the lack of effective strategic management at the level of enterprises, regions and industries, as well as complete indifference on the part of the state. Producers have a desire to grow and process industrial hemp, as evidenced by the number of companies that receive licenses for its production, the presence of a strong scientific base, varieties and technologies of cultivation. But the lack of plants for processing this crop almost nullifies the comprehensive development of this industry, acting mainly as a raw material appendage in the foreign market (Mykhailova \& Korenivska, 2020).

In a changing environment, passivity of the state in terms of investment work to create a processing complex of hemp, significant responsibility for the existence and development of the enterprise rests on the creative use of management tools and strategic management methods through concentration, ability to anticipate and calculate several options.

The use of strategic management tools will provide a qualitative strategic analysis, the ability to anticipate and adapt to changes in the external environment, to actively influence processes. Research shows that more sophisticated strategic tools and management methods are used in developed countries, followed by developing countries, and least in countries with economies in transition (Qehaja et al., 2017).

The choice of one or another method should be determined by the strategic priorities of enterpris- es for the production and processing of industrial hemp. For a long time, there was a clear trend to reduce costs of the enterprise, which influenced the choice of strategic management tools such as optimization and benchmarking. Gradually, the situation began to change by expanding the scope of activities and involving employees in management decisions.

The implementation of administrative-territorial reform in Ukraine provides an opportunity for communities to independently choose strategic priorities in achieving sustainable development of territories, including the cultivation of hemp. However, without the formation of a clear strategic hierarchy of management of the revival and development of the cannabis industry, state-industry-region-community-enterprise, positive changes are almost impossible to achieve. Strategic planning gives the best results in the situations when the most important changes can be foreseen in advance, the level of competition is stable, and the management process is carried out on the basis of centralization. The effectiveness of strategic management of the hemp industry depends on the optimal choice and effective use of appropriate tools.

According to the Strategy of Regional Development of Sumy region for the period up to 2027 (Strategy, 2020), it is planned to create an agritourism cluster of industrial hemp in order to develop a network of agritourism with the introduction of traditional and innovative technologies for growing and processing industrial hemp. This project is designed for three years with a planned funding of UAH 3,152 thousand (from 2021 to 2023). The planned number of cluster members is 17 , the number of estates is 5 , and the number of visitors is up to 3,000 .

Based on the results of the assessment of the cannabis industry in Ukraine, it is concluded that the formation of strategic management of hemp cultivation should be based on two key elements: improving institutional support and providing financial support. The first element will simplify too strict regulations for obtaining a license to conduct cannabis business and increase competition in the market of cannabis products. The second element is aimed at equalizing the income of producers in the field of crop production and 


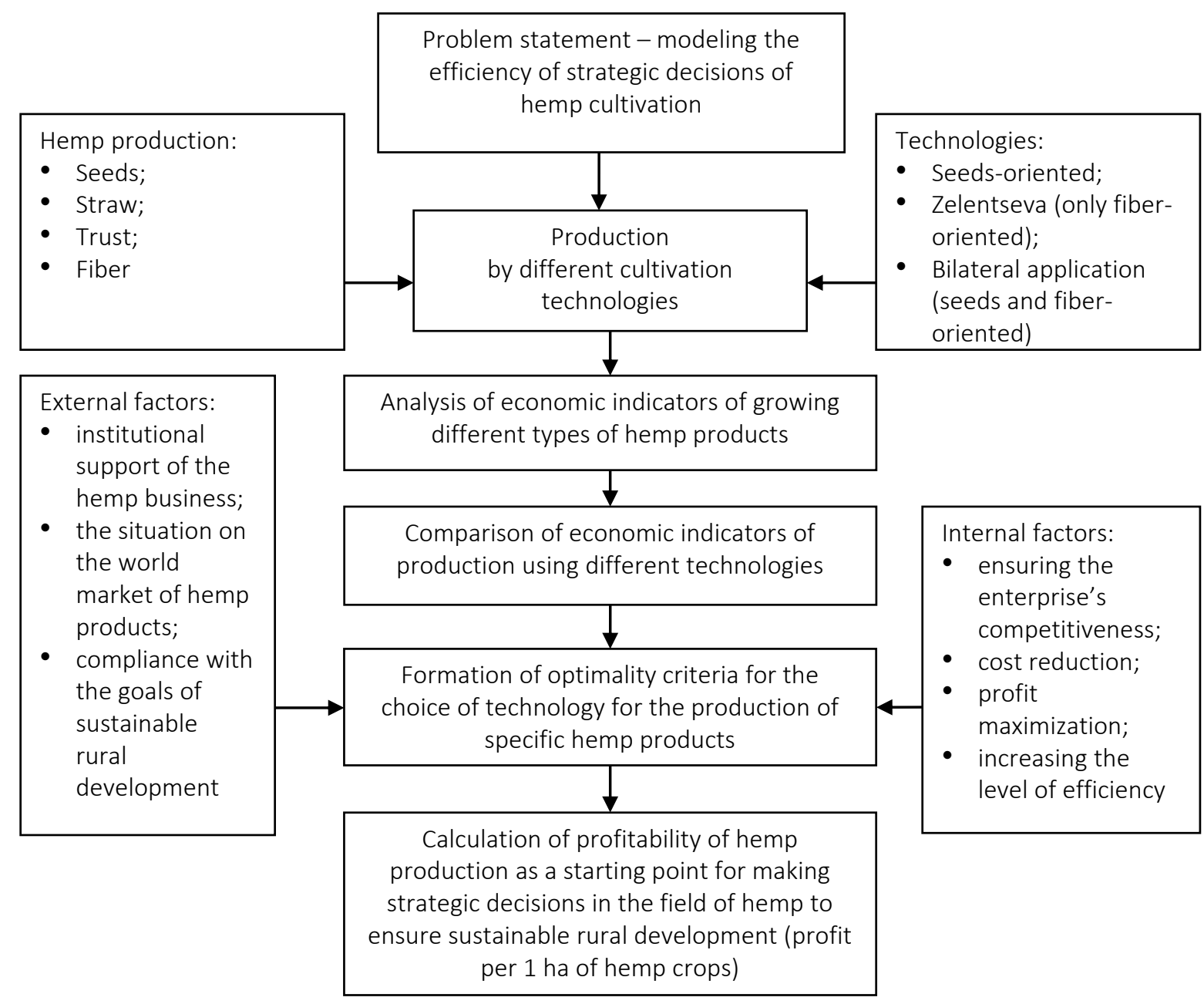

Figure 4. Algorithm for assessing the efficiency of strategic decisions in hemp cultivation

supporting the hemp business. The situation is characterized by an advantage in the cultivation of high-yielding, but not environmentally friendly crops (sunflower, rapeseed, corn). Hemp, like no other crop, is successfully grown without fertilizers and herbicides; not damaged by diseases and pests; most favorable for restoring soil fertility; in the long run it will create new jobs and economic growth in rural areas.

The choice of strategic management tools is also important. The formation of a strategy for the development of cannabis should include the following: mission definition, strategic planning, customer relationship management, benchmarking, employee involvement, and clear definition of the main guidelines for strategic management of the cannabis industry. Coordination of activities re- lated to the implementation of strategic goals between all participants in the hemp business and the creation of strategic planning and marketing services will increase the level of efficiency of enterprise management by expanding information security. The promotion of cannabis products on the market and the interest of investors will strengthen the image. Improving personnel policy will ensure the involvement of young professionals, staff training and, in general, improve the welfare of employees.

Strategic management of the cannabis industry requires constant improvement and updating of its instruments.

One of the important methodological tools for substantiating strategic decisions in the practice 
of hemp production is economic and mathematical modeling of their implementation. It is important to clearly set the task with the definition of variables and constraints, the choice of the objective function and taking into account the factors of influence of the external and internal environment, where management decisions will be implemented.

The proposed algorithm for substantiation of strategic decisions concerning hemp cultivation is presented in Figure 5.

From the presented algorithm (Figure 4) it can be argued that the determining factors of prerequisites for the profitability of strategic decisions are: production of a certain type of hemp products (seeds, straw, trust, fiber); selection of the most acceptable cultivation technology (seeds-oriented, zelentseva (only fiber-oriented), bilateral application (seeds and fiber-oriented); cost optimization; market conditions (price, demand, supply), etc.
Undoubtedly, the formulation of the economic and mathematical problem must consider the external factors of the hemp business such as legal regulations, volatility of the global hemp market, as well as its compliance with sustainable development goals. Variable indicators of the model are indicators of costs, yields and profits for the production of certain products by different technologies. The target function of modeling the effectiveness of a management decision can be indicators to ensure the competitiveness of the enterprise, reduce costs, maximize profits or increase the efficiency of resource use in the cultivation of hemp.

The application of the above algorithm to substantiate management decisions in the system of strategic management of hemp cultivation allows one to predict the main economic indicators of production of technical hemp products in the medium term. Thus, economic and mathematical modeling of the profitability of strategic decisions is an important and effective tool in the practice of strategic management of the hemp industry.

\section{CONCLUSION}

An assessment of the prospects for the revival of cannabis cultivation in Ukraine revealed a set of problems that cause stagnation in the cannabis industry. It is established that the main reasons for this are the lack of a sufficient number of cannabis processing plants and their remoteness from producers; complex regulatory policy; sharp fluctuations and instability of prices for hemp products; low public awareness and often hostile attitudes towards cannabis production, which hinders the strategic development of this industry. Due to the lack of strategic management in the industry and institutional and financial support for cannabis cultivation, Ukrainian cannabis is doomed to lose its export potential and deteriorate its position in the extremely liquid world market.

The defining guidelines for the strategic management of hemp cultivation should be: simplification of regulatory norms for producers; expansion of agribusiness entities; increase in production volumes; improved competitive environment in the cannabis market. To update the tools of strategic management, an algorithm for making managerial decisions is proposed. Its application in practice of substantiating the efficiency of strategies based on economic and mathematical modeling allows considering existing institutional conditions of manufacture of technical hemp and making forecasts of strategic scenarios for the development of the hemp branch.

\section{AUTHOR CONTRIBUTIONS}

Conceptualization: Liubov Mykhailova, Andrii Mykhailov, Liudmyla Korenivska.

Data curation: Liubov Mykhailova, Liudmyla Korenivska.

Formal analysis: Liubov Mykhailova, Liudmyla Korenivska, Lyudmyla Khromushyna.

Funding acquisition: Andrii Mykhailov, Liudmyla Korenivska, Lyudmyla Khromushyna,

Marharyta Chuprina. 
Investigation: Liudmyla Korenivska, Lyudmyla Khromushyna, Marharyta Chuprina.

Methodology: Liubov Mykhailova, Andrii Mykhailov, Liudmyla Korenivska, Lyudmyla Khromushyna, Marharyta Chuprina.

Project administration: Liubov Mykhailova, Andrii Mykhailov, Liudmyla Korenivska.

Resources: Liubov Mykhailova, Lyudmyla Khromushyna, Marharyta Chuprina.

Software: Andrii Mykhailov, Liudmyla Korenivska.

Supervision: Liubov Mykhailova.

Validation: Liubov Mykhailova.

Visualization: Andrii Mykhailov, Liudmyla Korenivska, Lyudmyla Khromushyna.

Writing - original draft: Liubov Mykhailova, Andrii Mykhailov, Liudmyla Korenivska,

Lyudmyla Khromushyna, Marharyta Chuprina.

Writing - review \& editing: Liubov Mykhailova, Andrii Mykhailov.

\section{REFERENCES}

1. Adesina, I., Bhowmik, A., Sharma, H., \& Shahbazi, A. (2020). A Review on the Current State of Knowledge of Growing Conditions, Agronomic Soil Health Practices and Utilities of Hemp in the United States. Agriculture, 10(4), 129. https://doi. org/10.3390/agriculture10040129

2. Antonov, A. (2010). Udoskonalennia systemy upravlinnia silskymy terytoriiamy [Improvement of rural territory management system]. Derzhavne upravlinnia: udoskonalennia ta rozvyitok - Public administration: improvement and development, 10. (In Ukrainian). Retrieved from http://www. dy.nayka.com.ua/?op=1\&z=531

3. Bzhuska, Ya., Pyka, Ya. (2012). Rozumna specializatsiia rehionu [Reasonable specialization of the region]. Visnyk Natsionalnoho universytetu "Lvivska politekhnika": Lohistyka. - Bulletin of the $\mathrm{Na}$ tional University "Lviv Polytechnic": Logistics, 749, 362-366. Retrieved from http://ena.lp.edu.ua

4. Carus, M. (2016). The European Hemp Industry. Retrieved September 10, 2018. Retrieved from https://hempedification.wordpress. com/2016/08/27/hemp-production-around-the-world/

5. Dukhnytsky, B.V. (2019). Potentsial rozvytku ahroprodovolchoho rynku Ukrainy [Development potential for the agro-food market in Ukraine]. Ekonomika APK - The Economy of AgroIndustrial Complex, 11, 27-34.
(In Ukrainian). Retrieved from https://doi.org/10.32317/22211055.201911027

6. D’yakonova, I., Nikitina, A., Sukhonos, V., \& Zhuravka F. (2018). Methodological bases of estimating the efficiency of economic security management of the enterprises in the global environment. Investment Management and Financial Innovations, 15(2), 145-153. https://doi.org/10.21511/ imfi.15(2).2018.13

7. Foray, D., David, P.A., \& Hall, B. (2009). Smart Specialization: The Concept. Knowledge for Growth. Prospects for Science. Technology, and Innovation. Selected papers from Research Commissioner Janez Potochnk's Expert Group, 20-24. Retrieved from https://clusterland.by/2019/11/19/ foray-d-david-p-a-hall-b-smartspecialization-the-concept-knowledge-for-growth-prospects-for-science-technology-and-innovationselected-papers-from-researchcommissioner-janez-potochnk/

8. Gilyazetdinov, R., Zhuplatova, L., \& Moher, Y. (2014). Naukovyi suprovid lionu ta konopli [Scientific support of flax and hemp industries]. Lubiani ta tekhnichni kultury: Zbirnyk naukovykh prats - Bast and industrial crops: Collection of scientific works, 3(8), 155. Sumy: Ellada Publishing House. (In Ukrainian).

9. Ihnatiuk, O. (2018). Chomu ukrayinski vyrobnyky konopel zalyshaiut vysokorentabelnyi biznes [Why Ukrainian cannabis producers are leaving a highly profitable business]. (In Ukrainian). Retrieved from https://agroinsider.com.ua/2018/06/22/chomuukra\%D1\%97nski-virobnikikonopel-jdut

10. Inverson, L. L. (2000). The Science of Marijuana (p. 302). USA: New York, Oxford University Press.

11. Kravets, K. (2014). Konceptsiia strategichnoho upravlinnia ahrarnymy pidpryiemstvamy Luhanskoi oblasti. [The concept of strategic management of agricultural enterprises in Luhansk region]. Ekonomichnyi analiz - Economic analysis, 16(2), 98-104.(In Ukrainian). Retrieved from http://econa.org.ua/index. php/econa/article/viewFile/447/ pdf_114

12. Marchenko, J. (2015). Napriamy vykorystannia konopleproduktsii u sviti. Lubiani ta tethnichni kultury [Areas of use of hemp products in the world. Bast and industrial crops]. Zbirnyk naukovykh prats - Collection of scientific works, 4(9), 159-166. Sumy: Ellada Publishing House. (In Ukrainian).

13. Marinchenko, I., \& Primakov, O. (2015). Ekonomichni aspekty vyrobnytstva konopel [Economic aspects of hemp production]. Bast and industrial crops: Collection of scientific works - Lubiani ta tekhichni kultury: Zbirnyk naukovykh prats, 4(9), 127-136. Sumy: Ellada Publishing House. (In Ukrainian). 
14. Migal, M., Pylypchenko, A., Sytnyk, V., \& Orlov, M. (2019). Nasinnytstvo konopel [Hemp seed production] (p. 264). Sumy, FOP Shcherbina I.V. (In Ukrainian).

15. Mykhailova, L., \& Korenivska, L. (2019). Haluz konopliarstva v systemi innovatsiinoho rozvytku silskykh terytorii. Problemy i perspektyvy innovatsiinoho rozvytku ahrarnoho sektora ekonomiky v umovakh intehratsiinykh protsesiv [Hemp industry in the system of innovative development of rural areas. Problems and prospects of innovative development of the agricultural sector of the economy in terms of integration processes]. Materials of International Science Practical Conference, 90th Anniversary of Economics Education in KhNAU named after V.V. Dokuchaev (pp. 94-97). October 3-4, Part 1. Kharkiv: KhNAU named after V.V. Dokuchaev. (In Ukrainian).

16. Mykhailova, L., Korenivska, L. (2020). Otsinka ekonomichnoho potentsialu vyrobnytstva konopel v Ukraini [Evaluation of the economic potential of the hemp production in Ukraine]. Ekonomika APK - APK Economics, 1 , 33. (In Ukrainian). Retrieved from https://doi.org/10.32317/22211055.202001033

17. Mykhailov, A., Makarova, V., Kapinos, N., \& Petrova, N. (2020). Land management's development in the period of land relations reform in Ukraine. Estudios de Economía Aplicada, 38(4). Retrieved from http://dx.doi. org/10.25115/eea.v38i4.3963

18. Patytska, K. (2019). Stratehiia smart-spetsializatsii v konteksti zabezpechennia konkurentnospromozhnosti rehionu: teoretychnyi aspekt [Smart specialization strategy in the context of regional competitiveness: theoretical aspect]. Efektyvna ekonomika - Efficient economy, 11. (In Ukrainian). https://doi.org/10.32702/23072105-2019.11.53

19. Qehaja, A. B., Kutllovci, E., \& Pula, J. S. (2017). Strategic Management Tools and Techniques: A ComparativeAnalysis of Empirical Studies. Croatian Economic Survey, 19(1), 67-99. Retrieved from https://www.researchgate. net/publication/318415733_Strategic_Management_Tools_and_ Techniques_A_Comparative_ Analysis_of_Empirical_Studies

20. Stratehiia rehionalnoho rozvytku Sumskoi oblasti na period do 2027 roku [Strategy of regional development of Sumy region for the period up to 2027]. (2020). Plan zakhodiv na 2021-2023 roky $z$ realizatsii stratehii rehionalnoho rozvytku Sumskoi oblasti na period do 2027 roku - Action plan for 2021-2023 to implement the strategy of regional development of Sumy region for the period up to 2027. (In Ukrainian). Retrieved from http://media.sm.gov.ua/images/docs/planzahod21-23.pdf

21. Tyler, M., Shepherd, J., Olson, D., Snell, W., Proper, S., \& Thornsbury, S. (2020). Economic Viability of Industrial Hemp in the United States: A Review of State Pilot Programs. Economic Information Bulletin, EIB-217. U.S. Department of Agriculture, Economic Research Service. Retrieved from https://www.ers.usda.gov/publications/pub-details/?pubid=95929

22. Ukrainian Institute for Plant Variety Examination (UIPVE). (2019). Derzhavnyi reiestr sortiv roslyin, prydatnykh dlia poshyrennia v Ukraini [State Register of Plant Varieties Suitable for Distribution in Ukraine]. (In Ukrainian). Retrieved from https://sops.gov.ua/ reestr-sortiv-roslin

23. Vilcina, A., Grinberga-Zalite G., \& Makovska, K. (2014). Development of hemp industry in the European Union and Latvia. Regional Formation and Development Studies, 14(3), 199-206. http://dx.doi. org/10.15181/rfds.v14i3.876

24. Yatsyuk, O. (2018) Smartspetsializatsiia rozvytku rehionu yak vazhlyvyi napriam pidvyshchennia jogo konkurentospromozhnosti ta innovatsiinoi aktyvnosti [Smart specialization of the region's development as an important direction of increasing its competitiveness and innovation activity]. Naukovyi visnyk Ivano-Frankivskoho natsionalnoho tekhichnoho universytetu nafty i hazu. Seriia: Ekonomika ta upravlinnia $v$ naftovii i hazovii promyslovosti - Scientific Bulletin of Ivano-Frankivsk National Technical University of Oil and Gas. Series: Economics and Management in the Oil and Gas Industry, 2, 54-60. (In Ukrainian). Retrieved from http://elar.nung.edu.ua/ handle/123456789/7015

25. Zhuplatova, L. M., Marynchenko, I. O., Moher, Yu. V., \& Prymakov, O. A. (2015). Lionarstvo ta konopliarstvo: suchasnyi stan i perspektyvy rozvytku [Flax growing and hemp growing: current state and prospects of development]. Innovations in flax and hemp - 2015: materials of the fourth research and practice conference (pp. 3-10). Sumy: Ellada Publishing House. (In Ukrainian). 